\title{
Effects of a Non-Rinse Conditioner on the Enamel of Primary Teeth
}

\author{
Marcelo FAVA ${ }^{1}$ \\ Silvio Issáo MYAKI ${ }^{1}$ \\ Victor Elias ARANA-CHAVEZ2 \\ Flavio FAVA-DE-MORAES ${ }^{2}$ \\ ${ }^{1}$ Discipline of Pediatric Dentistry, Faculty of Dentistry of São José dos Campos, UNESP, São José dos Campos, SP, Brazil \\ ${ }^{2}$ Department of Histology and Embriology, Institute of Biomedical Sciences, USP, São Paulo, SP, Brazil
}

\begin{abstract}
The aim of this in vitro study was to evaluate by scanning electron microscopy the morphological aspects of the enamel of primary teeth after etching with $36 \%$ phosphoric acid or a non-rinse conditioner. Ten naturally exfoliated anterior primary teeth were selected. The samples were subjected to prophylaxis with pumice paste and water using a low-speed hand piece. Etching was done on the buccal surface. Specimens were divided into 2 groups: G1 ( $n=10)$ : etching with 36\% phosphoric acid gel - Conditioner 36 (Dentsply) for 20 $\mathrm{s}$, followed by water rinse for $15 \mathrm{~s} ; \mathrm{G} 2$ ( $\mathrm{n}=10)$ : etching with NRC - Non Rinse Conditioner (Dentsply) for $20 \mathrm{~s}$, followed by air drying for $15 \mathrm{~s}$. The samples were dehydrated, mounted on metal stubs, coated with gold and observed with Jeol JSM-6100 scanning electron microscope. Electron-micrographic analysis showed that both etching agents were effective for etching the enamel of primary teeth causing the formation of microporosities on the enamel surface, although the etching pattern was more effective with the use of $36 \%$ phosphoric acid gel.
\end{abstract}

Key Words: dental enamel, deciduous tooth, acid etching.

\section{INTRODUCTION}

The technique of acid conditioning was introduced with the purpose of creating microporosities on the surface of the enamel, thus increasing the adherence of composites to that surface (1). Since that time, various authors have studied the retentive features of adhesive materials to the dental enamel. The type, concentration and duration of application of the etching agent are some of the variables that have been studied in recent years (2-4).

In the clinical setting, if the saliva of the etched dental enamel becomes contaminated, it can interfere with the quality of composite adhesion to the adamantine structure. It is assumed that contamination by saliva promotes the formation of an adhering film that covers the micropores that are created by the etching agent, impeding the formation of the resinous projections that are responsible for micromechanically retaining composites to the enamel (5) Traditionally, the etching of enamel is carried out through the application of phosphoric acid in concentrations that vary between 30 and $40 \%$, for a period of 15 to $30 \mathrm{~s}$.

Recently, a new etching agent was developed, the NRC (Non-Rinse Conditioner), which contains maleic and itaconic acids. This etching agent has the advantage of being able to be applied and then removed with a simple burst of compressed air, without the need for washing. This procedure may be of great importance in the practice of clinical pediatric dentistry, since it shortens the work time and thus reduces the risk of contaminated dental enamel, especially when conducted in the relative isolation of the operative field.

The aim of this in vitro study was to assess the effects of a non-washable etching agent on the enamel of deciduous teeth using scanning electronic microscopy.

\section{MATERIAL AND METHODS}

Ten anterior primary teeth were used. They were clinically healthy and naturally exfoliated. The samples 
selected were stored in saline solution at room temperature until the time of the experiment.

The teeth were cleaned using a rubber prophylaxis cup with pumice paste and water, mounted on a low-speed hand piece. Afterwards, the samples were washed with a spray of air and water for $20 \mathrm{~s}$ and then dried with compressed air from a triple syringe.

A groove was carved into the buccal surface of each sample, upward from the incisor surface, in order to divide the tooth into two halves on which to test the different etching methods. One half of the crown (control group) underwent etching with a gel containing 36\% phosphoric acid (Conditioner 36; Dentsply, Petrópolis, RJ, Brazil) for $20 \mathrm{~s}$, followed by a water wash of $15 \mathrm{~s}$. The other half of the crown (experimental group) underwent etching with a non-rinse conditioner (NRC - Non-Rinse Conditioner; Dentsply) for $20 \mathrm{~s}$, followed by $15 \mathrm{~s}$ of air-drying.

The samples were dehydrated in an increasing series of alcohol solutions (70-100\%). Immediately following this, they were dried, mounted on metal stubs and covered in gold with an Ions Sputter SCD/040

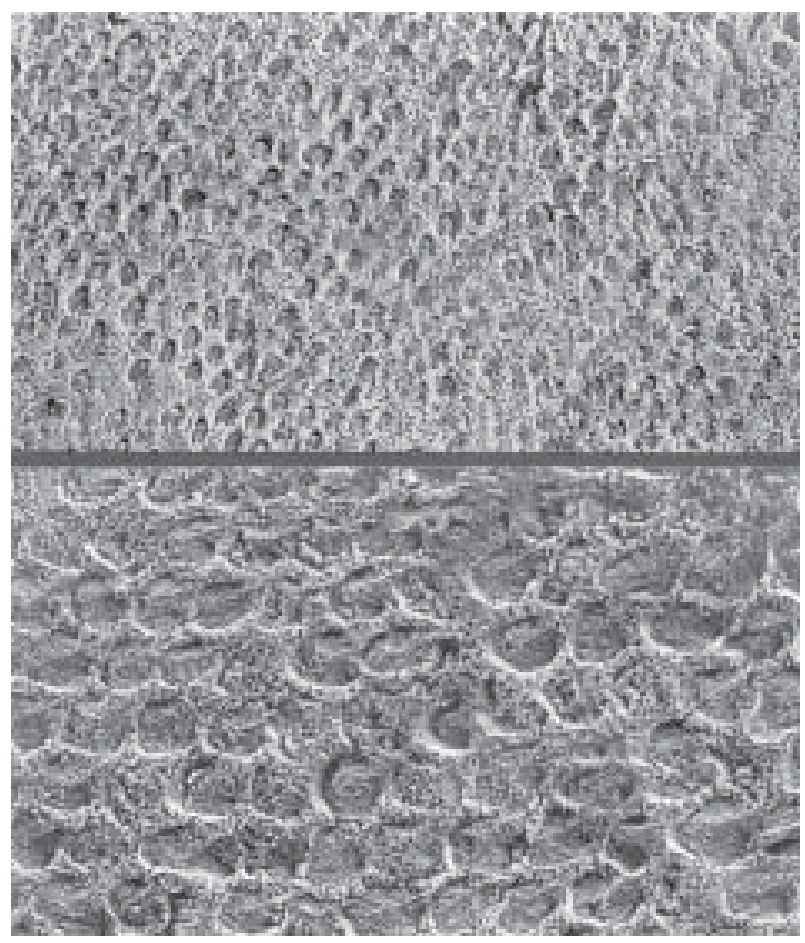

Figure 1. Morphological aspect of the surface of enamel conditioned with $36 \%$ phosphoric acid for $20 \mathrm{~s}$. The formation of micropores with type I pattern of conditioning can be observed. (Original magnification: top, 750X; bottom, 1500X). instrument for examination and were photographed with a Jeol JSM - 6100 electronic scanning microscope, set at $10 \mathrm{kV}$.

\section{RESULTS}

The electronmicrographs revealed that both etching agents created microporous formations on the enamel surface of deciduous teeth. However, a marked difference could be observed with the utilization of $36 \%$ phosphoric acid.

Figure 1 shows, in different degrees of detail, the enamel surface conditioned with $36 \%$ phosphoric acid for $20 \mathrm{~s}$, with the formation of micropores with preferential dissolution of the center (core) of the enamel prisms, characterizing the type 1 pattern (4).

The etching of the enamel surface with the nonrinse conditioner (NRC) for $20 \mathrm{~s}$ caused the formation of microporosities with preferential removal of the prism periphery material, characteristic of the type II pattern (4), as seen in Figure 2, at different levels of magnification.

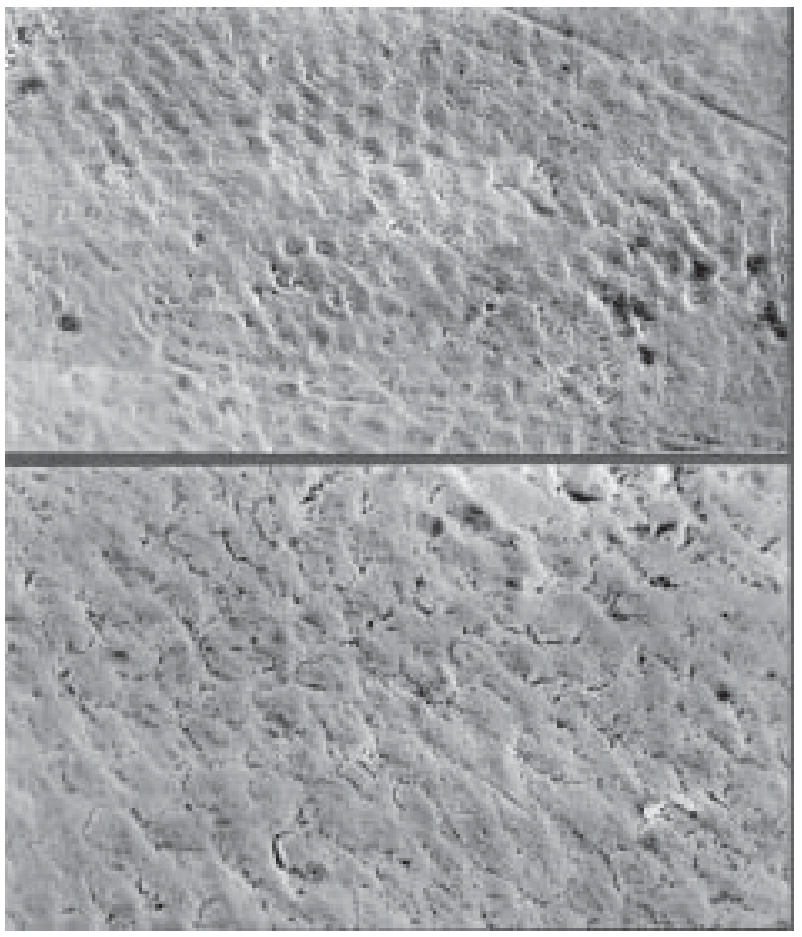

Figure 2. Morphological aspect of the surface of enamel conditioned with NRC. The formation of micropores with type II pattern of conditioning can be observed. (Original magnification: top, 750X; bottom, 1500X). 
In some specimens, the application of the nonrinse conditioning agent (NRC) created an undefined pattern of acid etching, as can be observed in Figure 3.

\section{DISCUSSION}

The utilization of different etching agents (36\% phosphoric acid or NRC) creates microporosities on the surface enamel of deciduous teeth $(6,7)$. However, this phenomenon was more clearly observed following the use of the $36 \%$ phosphoric acid.

Our results showed that the application of $36 \%$ phosphoric acid for $20 \mathrm{~s}$ caused the preferential dissolution of the center of the enamel prisms, classified as type I, in accordance with the literature (4). Similar results have also been observed on the buccal surface of deciduous molars $(2,6,7)$ and in permanent teeth $(3)$. This seems to be an important factor in the formation of resinous projections that contribute to the adequate adhesion of composites to the adamantine surface.

Less evident patterns of conditioning with the non-rinse conditioning agent were observed in agreement with the study of Fritz and Finger (8). They explained that phosphoric acid has a $\mathrm{pH}$ equal to 0.6 , while maleic acid contained in the NRC has a $\mathrm{pH}$ of 1.4. Thus, the higher $\mathrm{pH}$ of the acid component in NRC may not be sufficient to condition the surface enamel of deciduous teeth as effectively as $36 \%$ phosphoric acid.

The analysis and understanding of the different results obtained with the two types of etching agents is interesting when one considers that the two methodologies have the same objective and were applied in the same dental region, where it is known that the spatial orientation of the prisms is similar.

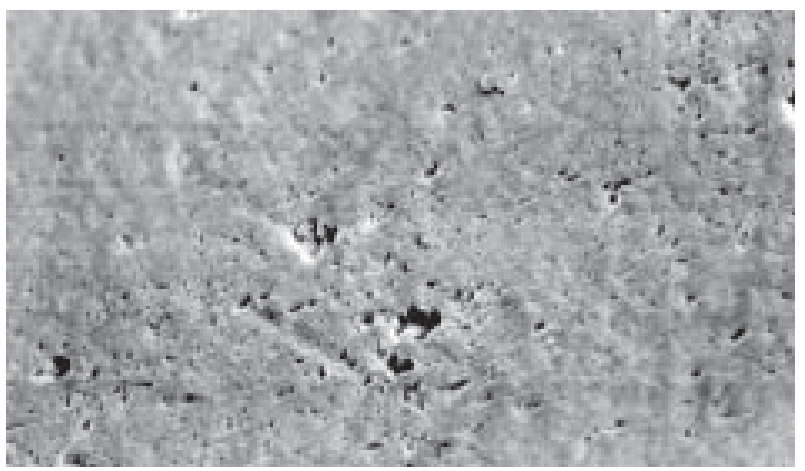

Figure 3. Morphological aspect of the surface of enamel conditioned with NRC presenting a pattern not defined by conditioning (Original magnification: 750X).
Clinically, the use of a non-rinse conditioning agent can be advantageous since it requires fewer and more reduced operational steps, resulting in a savings of time for preventive and/or restorative procedures, something that is particularly desirable in the treatment of children. Another advantage is that the reduced number of operational steps can diminish the risk of technical error.

It should be emphasized that the results of the present study are limited to the morphological aspects of the surface enamel after the use of different etching agents. Therefore, it is recommended that other studies be conducted in order to assess other aspects, such as adhesive resistance, microinfiltration, aspects of adhesive interface and clinical evaluation.

\section{RESUMO}

O objetivo deste estudo in vitro foi de avaliar ao microscópio eletrônico de varredura os aspectos morfológicos do esmalte de dentes decíduos após condicionamento com ácido fosfórico a $36 \%$ ou com um agente condicionador não lavável. Foram selecionados 10 dentes decíduos anteriores esfoliados naturalmente. As amostras sofreram limpeza coronária com pasta de pedra-pomes e água, em baixa-velocidade. O condicionamento foi realizado no esmalte da face vestibular. Os espécimes foram divididos em dois grupos: G1 $(\mathrm{n}=10)$ : condicionamento com ácido fosfórico a $36 \%$ na forma de gel - Conditioner 36 (Dentsply) durante 20 segundos, seguidos de lavagem com água durante 15 segundos; G2 ( $\mathrm{n}=10)$ : condicionamento com NRC - Non Rinse Conditioner (Dentsply) durante 20 segundos, seguidos de secagem com ar durante 15 segundos. As amostras foram desidratadas, montadas em bases metálicas e cobertas com ouro para análise ao microscópio eletrônico de varredura (Jeol JSM 6.100). A análise da eletromicrografias revelou que ambos os agentes condicionadores foram efetivos para condicionar o esmalte de dentes decíduos, causando microporosidades mas com melhor resultado quando utilizou-se o ácido fosfórico a $36 \%$ na forma de gel.

\section{REFERENCES}

1. Buonocore MG. A simple method of increasing the adhesion of acrylic filling materials to enamel surfaces. J Dent Res 1955;34:849-853.

2. Fava M, Myaki SI, Shintome LK, Watanabe I. Efeitos do condicionamento ácido sobre fissuras de molares decíduos Estudo in vitro ao microscópio eletrônico de varredura. J Bras Odontopediatr Odontol Bebê 2000;3:16-20

3. Glasspoole EA, Erickson RL, Davidson CL. Effect of enamel pretreatments on bond strength of compomer. Dent Mater 2001;17:402-408.

4. Silverstone LM, Saxton CA, Dognon IL, Sayerskov O. Variation in the pattern of acid etching of human dental enamel examined by scanning electron microscopy. Caries Res 1975;9:373-387. 
5. Silverstone LM, Hicks MJ, Featherstone MJ. Oral fluid contamination of etched enamel surfaces: an SEM study. J Am Dent Assoc 1985;110:329-332.

6. Costa LRRS, Watanabe I, Fava M. Study of prismless enamel in non-erupted human deciduous teeth. Braz J Morphol Sci 1996;13:219-223.
7. Shintome LK, Fava M, Myaki SI. Condicionamento ácido em diferentes regiões do esmalte de molares decíduos. Pós-Grad Rev Fac Odontol São José dos Campos 2001;4:28-32

8. Fritz U, Finger WJ. Bonding efficiency of single-bottle enamel/ dentin adhesives. Am J Dent 1999;17:277-282.

Accepted March 27, 2003 